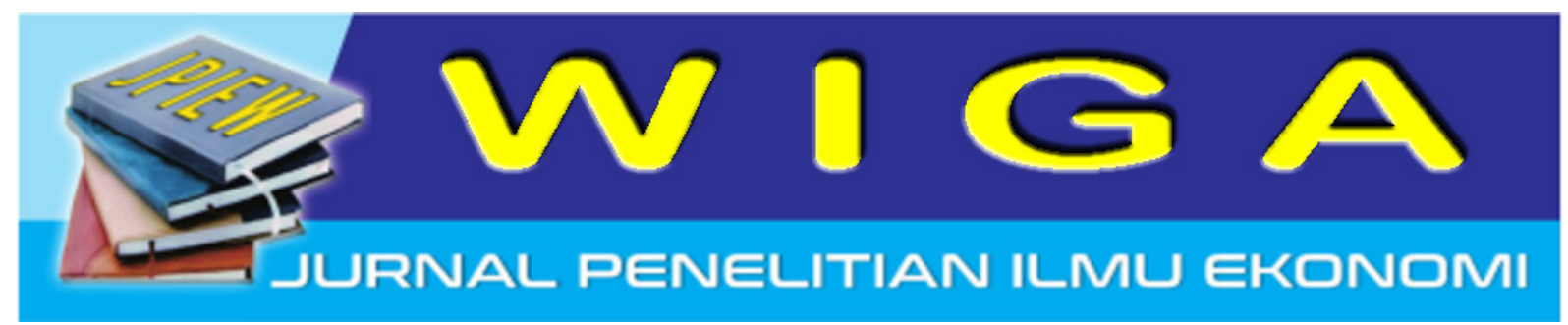

\title{
PENGARUH FASILITAS TERHADAP KEPUASAN PELANGGAN DI ASTON MADIUN HOTEL \& CONFERENCE CENTER
}

\author{
Ninik Srijani, Achmad Sukma Hidayat \\ Universitas PGRI Madiun \\ ninikikipae@gmail.com, ahmadsukmahidayat@gmail.com
}

\begin{abstract}
Abstrak:Penelitian ini bertujuan untuk mengetahui fasilitas di Aston Madiun Hotel \& Conference Center. Untuk mengetahui kepuasan pelanggan di Aston Madiun Hotel \& Conference Center. Untuk mengetahui adakah pengaruh fasilitas terhadap kepuasan pelanggan Aston Madiun Hotel \& Conference Center.Metode dalam penelitian ini adalah metode Deskriptif Kuantitatif, sedangkan teknik pengambilan sampel dalam penelitian ini adalah cluster sampling yaitu pelanggan yang menginap di Aston Madiun Hotel \& Conference Center dengan jumlah 101 responden. Pengumpulan data menggunakan menggunakan metode kuisioner dan observasi.Dalam menganalisis data instrumen yang digunakan adalah uji validitas dan reliabilitas.Untuk uji asumsi menggunakan uji normalitas. Dan untuk menguji hipotesis dari penelitian ini menggunakan analisis data regresi linier sederhana, koefisien determinan, dan uji t.Hasil penelitian diperoleh jumlah skor fasilitas mempunyai nilai di atas rata-rata sebanyak 59 responden, sedangkan di bawah rata-rata sebanyak 42 responden. $\mathrm{Y}=11,727+0,820 \mathrm{X}$. Konstanta sama dengan 11,727 , artinya apabila variabel Fasilitas bernilai tetap atau konstant, maka besarnya Kepuasan Pelanggan adalah 11,727. Artinya tanpa adanya pengaruh variabel Fasilitas maka Kepuasan Pelanggan akan tetap memiliki nilai sebesar 11,727. Koefisien regresi sebesar 0,820 memiliki pengertian bahwa apabila terjadi peningkatan variabel Fasilitas maka Kepuasan Pelanggan akan naik sebesar 0,820 satu satuan dengan asumsi variabel lain tetap. Koefisien bernilai positif berarti terjadi hubungan positif Fasilitas dan Kepuasan Pelanggan. Berdasarkan hasil analisis diatas dapat diketahui nilai $\mathrm{R}^{2}$ adalah 0,799. Jadi pengaruh fasilitas terhadap kepuasan pelanggan Aston Madiun Hotel \& Conference Center sebesar $79,9 \%$ sedangkan sisanya sebesar $20,1 \%$ dipengaruhi oleh faktor lain. Jadi dapat disimpulkan bahwa fasilitas mempunyai pengaruh terhadap kepuasan pelanggan. Perhitungan uji t diperoleh adalah 19,810 sedangkan $t_{\text {tabel }}$ sebesar 1,937. Dengan demikian $\mathrm{H}_{0}$ ditolak, artinya ada pengaruh fasilitas secara keseluruhan terhadap kepuasan pelanggan.
\end{abstract}

Kata Kunci: Fasilitas, Kepuasan Pelanggan

\begin{abstract}
This study aims to determine the facility in Aston Madiun Hotel \& Conference Center. To determine customer satisfaction at Aston Madiun Hotel \& Conference Center. To know the facility is there any influence on customer satisfaction Aston Madiun Hotel \& Conference Center. The method in this research is descriptive quantitative method, while the sampling technique in this research is cluster sampling, that customers who stayed at Aston Madiun Hotel \& Conference Center with a number of 101 respondents. Collecting data using questionnaires and observation methods. In analyzing the data the instruments used are validity and reliability. To test the assumption using normality test. And to test the hypothesis of this study using simple linear regression analysis of the data, the determinant coefficient, and $\mathrm{t}$ test. The results were obtained a total score of facilities has a value above the average of 59 respondents, while below the average of 42 respondents. $\mathrm{Y}=11.727+0,820 \mathrm{X}$. The constant equal to 11.727, meaning that if the variable or constant fixed-value amenities, the amount Customer Satisfaction is 11.727. This means that without the influence of the amenities variable customer satisfaction will continue to have a value of 11.727 . A regression coefficient of 0.820 has the sense that if an increase in
\end{abstract}


the Facility variables Customer satisfaction will rise by 0.820 of one unit assuming other variables remain. The coefficient is positive means that there is a positive relationship Facility and Customer Satisfaction. Based on the analysis above can be seen the value of R2 is 0.799 . So the influence of facilities to customer satisfaction Aston Madiun Hotel \& Conference Center $79.9 \%$ while the remaining $20.1 \%$ is influenced by other factors. So it can be concluded that the facility has an influence on customer satisfaction. $\mathrm{T}$ test calculations obtained was 19.810 while ttabel 1.937. Thus $\mathrm{H}_{0}$ is rejected, meaning that there is influence overall facility to customer satisfaction.

Keywords: Facilities, Customer Satisfaction

\section{PENDAHULUAN}

Perkembangan usaha dewasa ini telah diwarnai dengan berbagai macam persaingan di segala bidang. Melihat kondisi tersebut menyebabkan para pelaku bisnis semakin dituntut untuk mempunyai strategi yang tepat dalam memenuhi target volume penjualan. Dalam meningkatkan persaingan masingmasing perusahaan harus dapat memenangkan persaingan tersebut dengan menampilkan produk/jasa yang terbaik dan dapat memenuhi selera konsumen yang selalu berkembang dan berubah-ubah.

Keberadaan hotel di Kota Madiun sendiri baru-baru ini semakin meningkat seiring dengan perkembangan Kota Madiun baik infrastruktur maupun perekonomian di Kota Madiun.Hal ini membuat persaingan hotel semakin ketat, para pelaku bisnis hotel pun semakin meningkatkan kualitas produk (hotel) mereka baik dari segi fasilitas maupun pelayanan jasa hotel. Sebagai perusahaan yang bergerak di bidang pelayanan jasa tentunya Hotel Aston sangat memprioritaskan terkait dengan kenyamanan maupun kepuasan pelanggan, karena dengan meningkatkan pelayanan serta fasilitas-fasilitas hotel, hal itu tentunya juga akan berpengaruh terhadap kepuasan pelanggan pasca menginap di hotel tersebut.
Aston Madiun Hotel \& Conference Center merupakan hotel bisnis dan konferensi bintang 4 kontemporer, elegan dengan 125 kamar dan suite, memiliki berbagai ruang pertemuan serta konferensi termasuk grand ball room untuk kapasitas tamu sampai 1700 dan berbagai fasilitas rekreasi termurah seperti kolam renang dengan tempat berjemur, spa dengan layanan lengkap dan dilengkapi dengan fasilitas pusat kebugaran. Semua fasilitas di atas memiliki harga yang variatif sesuai dengan tipe kamar mulai dari yang paling standart IDR 428,000 ++.

Berdasarkan uraian di atas maka penulis mengadakan penelitian tentang “ Pengaruh Fasilitas Terhadap Kepuasan Konsumen di Aston Madiun Hotel \& Conference Center ".

Menurut Schnaars (dalam Tjiptono, 2008: 24), pada dasarnya tujuan dari suatu bisnis adalah untuk menciptakan para pelanggan yang merasa puas.

Terciptanya kepuasan pelanggan dapat memberikan beberapa manfaat, di antaranya hubungan antara perusahaan dan pelanggan menjadi harmonis, memberikan dasar yang baik bagi pembelian ulang dan terciptanya loyalitas pelanggan, dan membentuk suatu rekomendasi daari mulut ke mulut yang menguntungkan bagi perusahaan (Tjiptono dalam Tjiptono, 2008: 24) 
Dari penjelasan di atas dapat ditarik kesimpulan bahwa kepuasan merupakan tingkat akhir dari pemanfaatan fasilitas atau pelayanan.Hal ini disesuaikan dengan harapan yang telah di targetkan.

Kepuasan pelanggan ini dapat dikatakan merupakan titik penting dari suatu usaha oleh perusahaan jasa.Inilah hal yang dituju oleh suatu perusahaan jasa dimana pelanggan merasa ekspektasi mereka terhadap semua fasilitas atau pelayanan dapat terpenuhi dengan baik.

\section{Cara mengukur Kepuasan Pelanggan}

Menurut Kotler (dalam Buchari Alma, 2003: 285) Ada beberapa cara mengukur kepuasan pelanggan yaitu:

1) Complaint and suggestion system (Sistem keluhan dan Saran)

Banyak perusahaan membuka kotak saran dan menerima keluhan yang dialami oleh langganan.Ada juga perusahaan yang member amplop yang telah ditulis alamat perusahaan untuk digunakan menyampaikan saran, keluhan serta kritik.Saran tersebut dapat juga disampaikan melalui kartu komentar, customer hot line, telepon bebas pulsa.Informasi ini dapat memberikan ide dan masukan kepada perusahaan yang memungkinkan perusahaan mengantisipasi dan cepat tanggap terhadap kritik dan saran tersebut.

2) Customer satisfaction surveys (Survey kepuasan pelanggan)

Dalam hal perusahaan melakukan survai untuk mendeteksi komentar pelanggan Survey ini dapat dilakukan melalui pos, telepon, atau wawancara pribadi, atau pelanggan diminta mengisi angket.

3) Ghost shopping (pembeli bayangan)
Dalam hal ini perusahaan menyuruh orang tertentu sebagai pembeli ke perusahaan lain atau ke perusahaannya sendiri. Pembeli misteri ini melaporkan keunggulan dan kelemahan yang melayaninya.Juga dilaporkan segala sesuatu yang bermanfaat sebagai bahan pengambil keputusan oleh manajemen. Bukan saja orang lain yang disewa untuk menjadi pembeli bayangan tetapi juga manajer sendiri harus turun ke lapangan, belanja ke toko saingan dimana ia tidak di kenal. Pengalaman manajer ini sangat penting karena data dan informasi yang diperoleh langsung ia alami sendiri.

4) Lost customer analiysis (analisa pelanggan yang lari),

Langganan yang hilang, dicoba dihubungi, mereka diminta untuk mengungkapkan mengapa mereka berhenti, pindah ke perusahaan lain, adakah sesuatu masalah yang terjadi yang tidak bisa diatasi atau terlambat diatasi. Dari kontak semacam ini akan diperoleh informasi dan akan memperbaiki kinerja perusahaan sendiri agar tidak ada lagi langganan yang lari dengan cara meningkatkan kepuasan mereka.

Fasilitas adalah penyediaan perlengkapan-perlengkapan fisik untuk memberikan kemudahan kepada para tamu dalam melaksanakan aktivitasaktivitas atau kegiatan-kegiatannya, sehingga kebutuhan-kebutuhan dapat terpenuhi selama tinggal di hotel. (Sulistiyono, dalam Yunus \& Budianto, 2014:6)

Fasilitas merupakan tolak ukur dari semua pelayanan yang diberikan, serta 
sangat tinggi pengaruhnya terhadap kepuasan pelanggan.Karena dengan tingkat fasilitas yang ada juga sangat memudahkan pelanggan dalam beraktifitas serta nyaman untuk menggunakan fasilitas yang ada.

\section{Faktor-faktor Desain Fasilitas}

Menurut Moodie \& Cootam (dalam Tjiptono, 2007: 149) setidaknya terdapat enam faktor, yaitu ::

1. Perencaan spasial

Aspek-aspek seperti proporsi,simetri, tekstur, dan warna perlu diintregasikan dan dirancang secara cermat untuk menstimulasi respons intelektual maupun respons emosional dari para pemakai atau orang yang melihatnya.

2. Perencanaan ruangan

Faktor ini mencangkup perancangan interior dan arsitektur, seperti penempatan perabotan dan perlengkapannya dalam ruangan, desain aliran sirkulasi dan lain-lain.

3. Perlengkapan/perabotan

Perlengkapan/perabotan memiliki beberapa fungsi.Diantaranya sebagai sarana pelindung barang-barang berharga berukuran kecil, sebagai barang pajangan, sebagai tanda penyambutan bagi para pelanggan, dan sebagai sesuatu yang menunjukkan status pemilik atau penggunanya.

4. Tata cahaya

Beberapa hal yang perlu diperhatikan dalam mendesain tata cahaya adalah cahaya di siang hari (day lighting), warna, jenis dan sifat aktivitas yang dilakukan didalam ruangan, persepsi penyedia jasa akan tugasnya, tingkat ketajaman penglihatan, dan suasana yang diinginkan (tenang, damai, segar, riang, gembira, dan lain-lain).

5. Warna

Banyak orang yang menyatakan bahwa warna memiliki bahasanya sendiri, di mana warna dapat menstimulasi perasaan dan emosi spesifik.

6. Pesan-pesan yang disampaikan secara grafis

Aspek penting yang saling terkait dalam faktor ini adalah penampilan visual, penempatan, pemilihan bentuk fisik, pemilihan warna, pencahayaan, dan pemilihan bentuk perwajahan lambang atau tanda yang dipergunakan untuk maksud tertentu (misalnya, penunjuk arah/tempat, keterangan/informasi dan sebagainya).

\section{METODE PENELITIAN}

\section{Desain Penelitian}

Dalam penelitian yang digunakan dalam penelitian ini adalah hubungan kausal yang bersifat sebab akibat.Kemudian untuk jenis penelitian adalah penelitian kuantitatif.Sedangkan metode penelitian ini menggunakan metode deskriptif.

Berikut pemaparan desain penelitian yg terdiri dari variabel bebas (X) fasilitas dan variabel terikat (Y) kepuasan pelanggan :

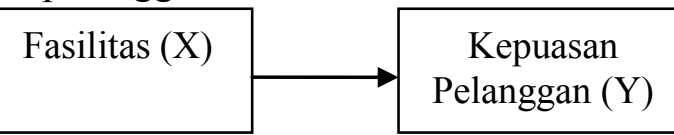

Di dalam penelitian ini, terdapat dua variabel yang digunakan, yaitu :

1. Variabel Independen (X) atau bebas

Variabel yang mempengaruhi atau yang menjadi sebab perubahannya atau timbulnya variabel terikat (dependen). (Hamid Darmadi, 
2013: 157). Variabel bebas (X) dalam penelitian ini adalah fasilitas.

2. Variabel dependen (Y) atau terikat

Variabel yang dipengaruhi atau yang menjadi akibat, karena adanya variabel bebas. (Hamid Darmadi, 2013: 157). Variabel terikat (Y) dalam penelitian ini adalah kepuasan pelanggan.

\section{Populasi}

Dalam penelitian ini tidak lepas dari adanya populasi yang merupakan seluruh unit yang akan diteliti. Untuk populasi penelitian ini sejumlah 135 pengunjung dalam kurun waktu 1 bulan.

\section{Sampel}

Sampel yang digunakan dalam penlitian ini adalah dari jumlah 135 pengunjung yang menginap di Aston Madiun Hotel \& Conference Center pada bulan Oktober 2016 terdapat 101 pelanggan yang dijadikan sampel.

Teknik pengumpulan data yang digunakan dalam penelitian ini adalah :

1) Kuisioner

Teknik pengumpulan data dalam penelitian ini adalah kuisioner dengan member butir-butir pernyataan pada responden.

2) Observasi

Kegiatan pengumpulan data juga menggunakan teknik observasi, yakni dengan melakukan pengamatan langsung obyek yang akan diteliti.

Dalam suatu penelitian, untuk menguji suatu data digunakan teknik untuk menganalisanya. Analisis yang dimaksudkan dalam penelitian ini adalah:

1. Uji prasarat atau Instrumen, diantaranya :

a. Uji Validitas

Dari semua item soal yang diberikan kepada responden
valid.Item soal dinyatakan valid karena nilai $r_{\text {hitung }} \geq r_{\text {tabel }}$ pada taraf signifikan yaitu 0.1937 . Dengan kata lain semua pernyataan valid dan dapat dipergunakan oleh peneliti sebagai instrumen penelitian.

b. Uji Reliabilitas

Hasil uji reliabilitas dinyatakan nilai reliabilitas konsisten internal sebesar 0,871, untuk koefisien alfa dinyatakan reliabel karena memiliki nilai> 0,6.Dengan demikian item pengukuran pada masing-masing indikator dalam variabel-variabel penelitian dinyatakan reliabel dan selanjutnya dapat digunakan dalam penelitian.

c. Uji Asumsi

Hasil uji normalitas yang terdapat di atas bahwa nilai Assymp Sig sebesar 0.200 lebih besar dari 0.05, dengan demikian dapat disimpulkan bahwa data yang akan dianalisis terdistribusi normal.

\section{HASIL PENELITIAN \\ Deskripsi Angket Fasilitas}

Dari hasil pengsisian angket Fasilitas dengan jumlah data $(\mathrm{N})$ sebanyak 101 responden mempunyai deskripsi data sebagai berikut: (a) Jumlah skor total sebesar 5477; (b) Nilai rata-rata hitung (mean) sebasar 54,23; (c) Median sebesar 54,00; (d) Modus sebesar 54; (e) Standar deviasi sebesar 8,536; (f) Nilai minimum sebesar 36; (g) Nilai maximum sebesar 73.

Hasil analisis deskriptif fasilitas yang di olah dari 101 responden yang menyatakan setuju terhadap fasilitas Aston Madiun Hotel \& Conference Center sebanyak 59 pelanggan atau 58,42 $\%$ di atas rata-rata dan sebanyak 42 
pelanggan atau $41,58 \%$ di bawah ratarata. Artinya kepuasan pelanggan banyak dipengaruhi oleh fasilitas.

\section{Deskripsi Angket Kepuasan Pelanggan}

Dari hasil pengisian angket Kepuasan Pelanggan dengan jumlah data (N) sebanyak 101 responden mempunyai deskripsi data sebagai berikut: (a) Jumlah skor total sebesar 5677; (b) Nilai rata-rata hitung (mean) sebasar 56,21; (c) Median sebesar 56,00; (d) Modus sebesar 64; (e) Standar deviasi sebesar 7,835; (f) Nilai minimum sebesar 39; (g) Nilai maximum sebesar 74 .

Hasil analisis deskriptif kepuasan pelanggan yang di olah dari 101 responden yang menyatakan sebanyak 52 pelanggan atau $51,49 \%$ di atas rata-rata dan sebanyak 49 pelanggan atau 48,51\% di bawah rata-rata. Artinya kepuasan pelanggan banyak dipengaruhi oleh fasilitas.

\section{Hasil Uji Regresi}

Dari hasil perhitungan, $\mathrm{Y}=11,727+$ $0,820 X$. Artinya apabila fasilitas meningkat sebanyak $1 \%$, maka kepuasan pelanggan akan meningkat sebesar 0,820 apabila faktor lain dianggap tetap.

\section{Hasil Uji Determinasi}

Dari hasil perhitungan dapat diketahui besarnya nilai $r_{\text {hitung }}$ adalah 0,894 sedangkan $r_{\text {tabel }} 0,1937$. Ini berarti bahwa nilai $r_{\text {hitung }} \geq r_{\text {tabel }}(0,894 \geq$ 0,1937), atau dapat disimpulkan tolak $\mathrm{H}_{0}$, artinya ada pengaruh antara Fasilitas terhadap Kepuasan Pelanggan Aston Madiun Hotel \& Conference Center.

\section{Hasil Uji T}

Dari tingkat signifikan $\mathrm{T}$ hitung 19,810 lebih besar dari $\mathrm{T}$ tabel 1,937 $(19,810>1,937)$, maka hipotesis penelitian ini menerima Ha dan menolak Ho. Hipotesis yang menyatakan menerima Ha menunjukkan bahwa variabel Fasilitas ada pengaruh yang signifikan terhadap Kepuasan Pelanggan.

\section{SIMPULAN DAN SARAN}

\section{Simpulan}

Penelitian ini bertujuan untuk mencari pengaruh antara Fasilitas terhadap Kepuasan Pelanggan Aston Madiun Hotel \& Conference Center.Berdasarkan hasil analisis data pada pembahasan bab sebelumnya, maka dapat diambil kesimpulan sebagai berikut:

1. Fasilitas di Aston Madiun Hotel \& Conference Center.

Responden dalam penelitian ini yakni pelanggan yang menginap di Aston Madiun Hotel \& Conference Center yang telah mempersepsikan fasilitas di Aston Madiun Hotel \&Conference Center.Fasilitas sangat berpengaruh pada pelanggan di Aston Madiun Hotel \& Conference Center.Hal ini dapat dilihat dari hasil pengisian kuesioner yang telah dilakukan oleh responden. Dari 101 responden yang mengisi kuisioner fasilitas sebanyak 59 pelanggan atau $58,42 \%$ di atas rata-rata dan sebanyak 42 pelanggan atau $41,58 \%$ di bawah rata-rata.

2. Kepuasan Pelanggan Aston Madiun Hotel \& Conference Center cukup tinggi. Hal ini dapat dilihat dari 101 responden yang mengisi kuisioner kepuasan pelanggan sebanyak 52 pelanggan atau $51,49 \%$ di atas ratarata dan sebanyak 49 pelanggan atau $48,51 \%$ di bawah rata-rata.

3. Pengaruh Fasilitas terhadap Kepuasan Pelanggan di Aston Madiun Hotel \& Conference Center. 
a. Uji regresi, $\mathrm{Y}=11,727+0,820 \mathrm{X}$. Artinya apabila fasilitas meningkat sebanyak $1 \%$, maka kepuasan pelanggan akan meningkat sebesar 0,347 apabila faktor lain dianggap tetap.

b. Uji determinasi, dapat diketahui besarnya nilai $r_{\text {hitung }}$ adalah 0,894 sedangkan $r_{\text {tabel }}$ 0,1937. Ini berarti bahwa nilai $r_{\text {hitung }} \geq r_{\text {tabel }}(0,894 \geq$ 0,1937), atau dapat disimpulkan tolak $\mathrm{H}_{0}$, artinya ada pengaruh antara Fasilitas terhadap Kepuasan Pelanggan di Aston Madiun Hotel $\&$ Conference Center.

c. Uji t, dari tingkat signifikan $\mathrm{T}$ hitung 19,810 lebih besar dari $\mathrm{T}$ tabel 1,937 $(19,810>1,937)$, maka hipotesis penelitian ini menerima Ha dan menolak Ho. Hipotesis yang menyatakan menerima $\mathrm{Ha}$ menunjukkan bahwa ada pengaruh signifikan antara variabel Fasilitas terhadap Kepuasan Pelanggan di Aston Madiun Hotel \& Conference Center.

Berdasarkan penelitian yang telah dilakukan dapat diiterprestasikan bahwa apabila suatu perusahaan atau hotel khususnya Aston Madiun Hotel \& Conference Center memperhatikan kelengkapan serta kenyamanan fasilitas yang tersedia, maka secara langsung atau tidak langsung akan menimbulkan rasa kepuasan dari pelanggan.

\section{Saran}

Berdasarkan hasil penelitian yang telah diuraikan dalam kesimpulan di atas, maka dalam penelitian ini disampaikan beberapa saran sebagai berikut:
1. Bagi Aston Madiun Hotel \& Conference Center

Berdasarkan hasil penelitian yang telah dilakukan mengenai fasilitas terhadap kepuasan pelanggan, maka perusahaan dapat menjadikannya sebagai bahan kajian guna menambah kualitas pelayanan hotel terhadap tamu, baik dengan menambah fasilitas maupun dengan peningkatan layanan dari karyawan. Dengan itu produk jasa yang diberikan akan menjadi kepuasan oleh pelanggan, sehingga mampu meningatkan reputasi produk hotel.

2. Bagi Masyarakat

Dengan adanya penelitian ini, diharapan mampu menjadi referensu bagi mayarakat dalam menggunakan produk jasa hotel.Dari sini masyarakt dapat mengetahui bagaimana fasilitasfasilitas hotel yang baik, serta mengetahui produk-produk kita.

3. Bagi Civitas Akademika

Bagi peneliti yang tertarik ingin melakukan penelitian selanjutnya khususnya tentang pengaruh fasilitas terhadap kepuasan pelanggan, peneliti dapat menambahkan variabel lainnya untuk penelitian selanjutnya.Misalnya adanya variabel, kualitas pelayanan, citra perusahaan, loyalitas pelanggan, kepuasan konsumen, dan lain-lain.

\section{DAFTAR PUSTAKA}

Alma, B. 2013.Manajemen Pemasaran Dan Pemasaran Jasa. Bandung. Alfabeta.

Arikunto, S. 2013. Prosedur Penelitian Suatu Pendekatan Praktik. Jakarta. Rineka Cipta.

Badri, S. 2012. Metode Statistika Untuk Penelitian Kuantitatif. Yogyakarta. Penerbit Ombak.

Darmadi, H. 2013. Dimensi-Dimensi Metode Penelitian Pendidikan Dan Sosial. Bandung. Alfabeta. 
Ghozali, I. 2011. Aplikasi Analisis Multivariate Dengan Program IBM SPSS 19. Semarang: Badan Penerbit Universitas Diponegoro.

Herlambang, F. 2014. Basic Marketing (Dasar-Dasar

Pemasaran).Yogyakarta. Gosyen Publishing.

Lovelock, C., Dkk. 2011.Pemasaran Jasa Prespektif Indonesia Jilid 1 Edisi Ketujuh. New Jersey. Penerbit Erlangga.

Mamang, E., Dan Sopiah. 2013. Perilaku Konsumen. Yogyakarta. Penerbit Andi.

Martono, N. 2012.Metode Penelitian Kuantitatif Analisis Isi Dan Analisis Data Sekunder. Jakarta. Rajagrafindo Persada.

Muljadi. 2010. Kepariwisataan Dan Perjalanan. Jakarta. Rajagrafindo Persada.

Noor, J. 2011. Metode Penelitian: SKRIPSI, TESIS, DISERTASI, DAN KARYA ILMIAH. Jakarta. Prenada Media Group.

Priyatno, D. 2013. Analisis Korelasi, Regresi, Dan Multivariate Dengan SPSS.Yogyakarta.Penerbit Gava Media.

Siregar, S. 2012. Statistika Deskriptif Untuk Penelitian. Jakarta. Rajagrafindo Persada.

Siregar, S. 2014. Statistika Parametric Untuk Penelitian Kuantitatif. Jakarta. Bumi Perkasa.

Sugiyono. 2008. Statistika Untuk Penelitian. Bandung. Alfabeta.

Sugiyono. 2013. Metode Penelitian Kombinasi (Mixed Methods). Bandung. Alfabeta.

Sugiyono. 2014. Metode Penelitian Kombinasi (Mixed Methods). Bandung. Alfabeta.

Sugiyono. 2015. Metode Penelitian Kuantitatif Kualitatif Dan $R \& D$. Bandung. Alfabeta.

Tjiptono, F. 2007. Pemasaran Jasa. Malang. Bayumedia Publishing.
Tjiptono, F. 2008. Strategi Pemasaran.Yogyakarta. Andi Offset.

Tjiptono, F. \& Chandra, G. 2011.Service, Quality \& Satisfaction Edisi 3. Yogyakarta. Andi Offset.

Umar, H. 2011. Metode Penelitian Untuk Skripsi Dan Tesis Bisnis. Jakarta. PT Rajagrafindo Persada.

Yunus Dan Budiyanto. 2014. Pengaruh Kualitas Pelayanan Dan Fasilitas Terhadap Kepuasan Pelanggan. Jurnal Ilmu \& Riset Manajemen Vol 3, No 12, (Ejournal.Stiesia.Ac.Idindex.Phpjirm articledownload682652, Di Unduh 26 Mei 2016) 